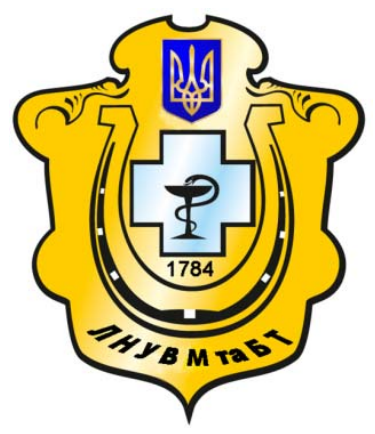

Науковий вісник Львівського національного університету ветеринарної медицини та біотехнологій імені С.3. Гжицького

Scientific Messenger of Lviv National University of Veterinary Medicine and Biotechnologies named after S.Z. Gzhytskyj

doi:10.15421/nvlvet6627

ISSN 2413-5550 print

ISSN 2518-1327 online

$\underline{\text { http://nvlvet.com.ua/ }}$

УДК 57.08:611.013.46:636.7

\title{
До методу отримання мезенхімальних стовбурових клітин великої рогатої худоби
}

\author{
А.Й. Мазуркевич, А.В. Грищук \\ amaz@nauu.kiev.ua, vet-lubny@yandex.ru \\ Національний університет біоресурсів і природокористування Украӥни, \\ вул. Героїв Оборони, 11, м. Київ, 03041, Україна
}

Перспективність отримання $і$ застосування мультипотентних мезенхімальних стовбурових клітин дорослого організму, визначається їх основними властивостями і ознаками. Диплоїдні культури клітин, отримані із тканин $і$ органів ссавиів, зберігають свою видову і тканинну специфічність, але мають обмежений період проліферачії внаслідок старіння. Тому використання мезенхімальних стовбурових клітин є актуальним. Легкість їх виділення і доступність біологічного матеріалу робить їх, на сьогоднішній день, найбільш перспективною клітинною системою. Дослідження властивостей стовбурових клітин у ветеринарній медицині має свої особливості. Вони полягають, зокрема, у врахуванні видових характеристик досліджуваного клітинного матеріалу, щро має важливе значення в практичній регенеративній ветеринарній терапії. $B$ результаті проведеної роботи, було відпрачьовано методи отримання, культивування $і$ глибокого заморожування культур мультипотентних мезенхімальних стовбурових клітин, виділених з кісткового мозку великої рогатої худоби. Порівняльний аналіз ефективності виділення мезенхімальних стовбурових клітин при використанні гепарину, або ичитрату натрію вказує на не суттєві відмінності і можуть використовуватись обидва препарати. При культуванні мезенхімальних стовбурових клітин методом розділення клітин в градієнті щүільності фікола є більш ефективним, хоча і другий метод також може бути.

Ключові слова: кістковий мозок, мезенхімальні стовбурові клітини, методика, велика рогата худоба

\section{К методам получения мезенхимальных стволовых клеток крупного рогатого скота}

\author{
А.Й. Мазуркевич, А. В. Грищук \\ amaz@nauu.kiev.ua, vet-lubny@yandex.ru
}

Национальный университет биоресурсов и природопользования Украины,, г. Киев, Украина ул. Героев Обороны, 11, Киев, 03041, Украина

Перспективность получения и применения мультипотентных мезенхимальных стволовых клеток взрослого организма, определяется их основными свойствами и признаками. Диплоидные культуры клеток, полученные из тканей и органов млекопитающих, сохраняют свою видовую и тканевую специфичность, но имеют ограниченный период пролиферации в результате старения. Поэтому использование мезенхимальных стволовых клеток актуально. Легкость их выделения и доступность биологического материала делает их, на сегодняшний день, наиболее перспективной клеточной системой. Исследования свойств стволовых клеток в ветеринарной медииине имеют свои особенности. Они заключаются, в частности, в учете видовых характеристик исследуемого клеточного материала, что имеет важное значение в практике регенеративной ветеринарной терапии. В результате проведенной работы, были отработаны методы получения, культивирования и глубокого замораживания культур мультипотентных мезенхимальных стволовых клеток, выделенных из костного мозга крупного рогатого скота. Сравнительный анализ эффективности выделения мезенхимальных стволовых клеток при

\section{Citation:}

Mazurkevych, A.Y., Hryshchuk. A.V. (2016). Method for obtaining mesenchymal stem cells cattle. Scientific Messenger LNUVMBT named after S.Z. Gzhytskyj, 18, 2(66), 132-135. 
использовании гепарина или цчитрата натрия указывает на несущественные отличия, и могут использоваться оба препарата. Культивирование мезенхимальных стволовых клеток методом разделения клеток в градиенте плотности фикола более эффективно, хотя и второй метод тоже может быть.

Ключевые слова: костный мозг, мезенхиальные стволовые клетки, методика, крупный рогатый скот.

\title{
Method for obtaining mesenchymal stem cells cattle
}

\author{
A.Y. Mazurkevych, A.V. Hryshchuk \\ amaz@nauu.kiev.ua, vet-lubny@yandex.ru \\ National University of life and environmental sciences of Ukraine, \\ Heroyiv Oborony Str., 11, Kyiv, 03041, Ukraine
}

\begin{abstract}
Prospects receipt and use of multipotent mesenchymal stem cells of an adult organism, determined by their basic properties and characteristics. Diploid cell cultures derived from mammalian tissues and organs, preserve their species and tissue specificity, but have a limited period of proliferation because of aging. Therefore, the use of mesenchymal stem cells is important. The ease of selection and availability of biological material makes them today to date, the most promising cell system. Studying the properties of stem cells in veterinary medicine has its own characteristics. They are in particular, taking into account specific characteristics of the cell material, which is important in practical veterinary regenerative therapy. There is a significant amount of minutes of culturing mesenchymal stem cells, but none of the authors do not focuses on the expression of biological properties of these cells by culturing. In the study of the biological properties of mesenchymal stem cells, there are many mysteries and the unknown, but today conducted preclinical and clinical studies for the introduction of these cells to correct the damaged organs and tissues of an animal body. Thus, the study and knowledge of the underlying mechanisms that form the specific features of the biological properties of stem cells in cattle is important and urgent to develop scientifically based methods of use of mesenchymal stem cells in regenerative therapy of breast diseases in cows. Because of this work was perfected method of cultivation and crop deep freeze multipotent mesenchymal stem cells isolated from bone marrow of cattle. In studies we used mesenchymal stem cells derived from bone marrow of healthy donor cows. For bone marrow, we used our improved method. Comparative analysis of the efficiency of the allocation of mesenchymal stem cells using heparin or sodium citrate indicates no significant differences and can be used both drugs. When cultured mesenchymal stem cells by cell separation density gradient fikola is more efficient, while the second method also can be. The proposed method of obtaining and culturing multipotent mesenchymal stem cells isolated from bone marrow of cattle makes it possible to obtain stem cells with high biological activity.
\end{abstract}

Key words: bone marrow, mesenchymal stem cells, methods, cattle

\section{Ветуп}

Перше повідомлення про існування стовбурових клітин було доведено до наукової спільноти російським вченим Максимовим А.А. Ще в 1908 році А.А. Максимов ввів термін «стовбурова клітина», для пояснення механізму швидкого самовідновлення клітин крові. Пізніше професор Фріденштейн підтвердив здогади колеги, і вивчаючи можливості цих клітин, став розробляти методи застосування стовбурових клітин на практиці (Fridenshtejn et al., 1970; Minguell, 2001).

Мезенхімальні стовбурові клітини ссавців на сьогодні вважаються найбільш перспективним видом аутогенного й алогенного матеріалу для клітинної терапії (Mazurkevych et al., 2013).

Сучасний етап розвитку регенеративної медицини характеризується стрімким прогресом біотехнологій, що є наслідком, передусім, успіхів у дослідженні біологічних властивостей стовбурових клітин.

Дослідження властивостей стовбурових клітин у ветеринарній медицині має свої особливості. Вони полягають, зокрема, у врахуванні видових характеристик досліджуваного клітинного матеріалу, що має важливе значення в практичній регенеративній ветеринарній терапії.

Як відомо, диплоїдні клітин, отримані із тканин і органів ссавців, в культуральному середовищі зберігають свою видову і тканинну специфічність, але мають обмежений період проліферації внаслідок ста- ріння. Тому використання мезенхімальних стовбурових клітин $є$ актуальним. Легкість їх виділення і доступність біологічного матеріалу робить їх на сьогоднішній день найбільш перспективною клітинною системою (Volkova et al., 2012; Mazurkevych et al., 2013).

Перспективність отримання і застосування мультипотентних мезенхімальних стовбурових клітин дорослого організму визначається їх основними властивостями і ознаками. Достовірно встановлено, що мезенхімальні стовбурові клітини стабільно самовідновлюються в клонах без анеуплодії, генетичної нестабільності і малігнізації. При цьому вони здатні проліферувати в культурі тривалий час, формуючи стабільні диплоїдні клітинні лінії. При індукції до диференціювання, клітини здатні диференціюватись в декількох напрямках, утворюючи in vitro клітини інших тканин (Smith et al., 2003; Volkova et al., 2012; Mazurkevych et al., 2013).

Існує значна кількість протоколів культивування мезенхімальних стовбурових клітин, проте жоден із авторів не акцентує увагу на прояв біологічних властивостей цих клітин при культивуванні (Mazurkevych et al., 2013).

У вивченні біологічних властивостей мезенхімальних стовбурових клітин існує багато загадок та невідомого, проте уже сьогодні проводяться доклінічні й клінічні дослідження щодо введення цих клітин 3 метою корекції ушкоджених органів і тканин тваринного організму (Savchenkova and Guljukin, 2011). 
Таким чином, вивчення і знання глибинних механізмів, які формують видові особливості біологічних властивостей стовбурових клітин організму великої рогатої худоби, є важливим і досить актуальним для розробки науково обгрунтованих методів застосування мезенхімальних стовбурових клітин у регенеративній терапії хвороб молочної залози у корів.

\section{Матеріал і методи досліджень}

В дослідженнях нами використані мезенхімальні стовбурові клітини, отримані із кісткового мозку здорових корів-донорів. Для отримання кісткового мозку ми використали вдосконалену нами методику.

Для попередження процесів згортання крові в отриманій клітинній масі ми додавали до однієї порції отриманого аспірату кісткового мозку гепарин у співвідношенні 2-3 ОД на $1 \mathrm{~cm}^{3}$, до іншої- цитрат натрію в кількості 1-2 мл на $10 \mathrm{~cm}^{3}$. До зразків аспірату кісткового мозку додавали також подвійну дозу (20 мкл) антибіотика-антимікотика. Шприци з аспіратом поміщали в термоконтейнер з холод елементами і протягом 3 - 4 годин доставляли в лабораторію НУБіП для використання їх в подальших дослідженнях.

Для виділення 3 кісткового мезенхімальних стовбурових клітин використовували два методи. Перший - розділення клітин в градієнті щільності фіколу за методом, розробленим в лабораторії НУБіП.

Суть методу полягає в тому, що отриманий аспірат розводили фосфатно-буферним розчином у три рази. Далі розбавлену клітинну масу із аспірату кісткового мозку нашаровували на градієнт фіколу $(\rho=1,076)$. Потім пробірки з нашарованим фіколом центрифугували при кімнатній температурі 30 хвилин при 1000 об./хв. Для уникнення перемішування при центрифугуванні використовували поступове гальмування ротора. В процесі такого центрифугування клітини крові осідали на дно пробірки. На межі розподілу шарів формувалася фракція одноядерних клітин у вигляді опалесцюючого шару, який обережно збирали піпеткою. Далі фракцію одноядерних клітин промивали фосфатно-буферним розчином 1:1 і повторно центрифугували 5 хвилин, але при 1700 об./хв. Отриману суспензію клітинної маси висівали у культуральні чашки Петрі (d=60 мм) і культивували до отримання моношару 80\%-ої конфлюентності. Отриману культуру клітин культивували за стандартною методикою в культуральних чашках Петрі та $\mathrm{CO}_{2}$ інкубаторі (t $37^{\circ} \mathrm{C}, 5$ \% $\mathrm{CO}_{2}$ ), використовуючи поживне середовище такого складу: 80 \% - DMEM, $20 \%$ ембріональна сироватка теляти 3 додаванням 10 мкл/см ${ }^{3}$ середовища антибіотика-антимікотика. Заміну середовища проводили через кожні три доби.

За другим методом проводили центрифугування аспірату протягом 5 хвилин при 1,7 тис. обертів/хв. Далі до надосадкової рідини додавали 80\% - DMEM, $20 \%$ - ембріональної сироватки теляти 3 додаванням подвійної дози 20 мкл/ $\mathrm{cm}^{3}$ середовища антибіотикаантимікотика, висівали в чашки Петрі і поміщали в $\mathrm{CO} 2$-інкубаторі (t $37^{\circ} \mathrm{C}, 5 \% \mathrm{CO}_{2}$ ). Заміну середовища проводили також через кожні три доби.
При досягненні моношару 80\%-ої конфлюентності, клітини переводили в суспензію, використовуючи 0,5\%-й розчин трипсину/ЕДТА і розсівали у співвідношенні 1:2.

Готові культури клітин, отримані за двома методами, переносили для зберігання в посудині Дюара із рідким азотом. Перед кріоконсервуванням культуру клітин переносили у середовище, що складається із фетальної телячої сироватки та 10\% ДМСО.

\section{Результати та їх обговорення}

У серії досліджень після висівання клітинного матеріалу в культуральні чашки Петрі та в процесі його культивування проводили оцінку характеру біологічної активності стовбурових клітин за показником утворення колоній. Під час мікроскопічного дослідження було виявлено вже на 7 день культивування значну кількість колоній. Характерною ознакою росту стовбурових клітин $є$ те, що вони мають видовжену форму і прикріплюються до дна чашки (мал. 1 - 3).

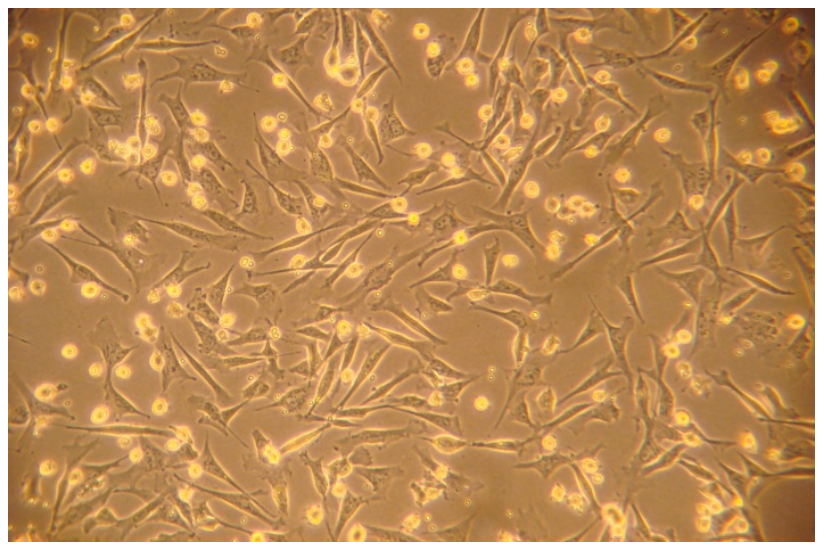

Рис.1. Колонії стовбурових клітин, отриманих фікольним методом з гепарином;

7 день культивування, збільшення 10х30.

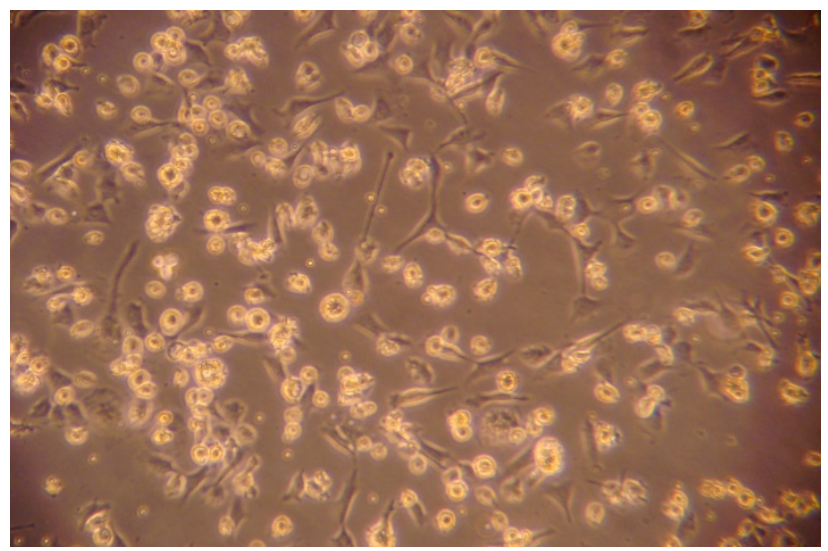

Рис. 2. Колонії стовбурових клітин, отриманих фікольним методом 3 цитратом натрію; 7 день культивування, збільшення $10 x 30$. 


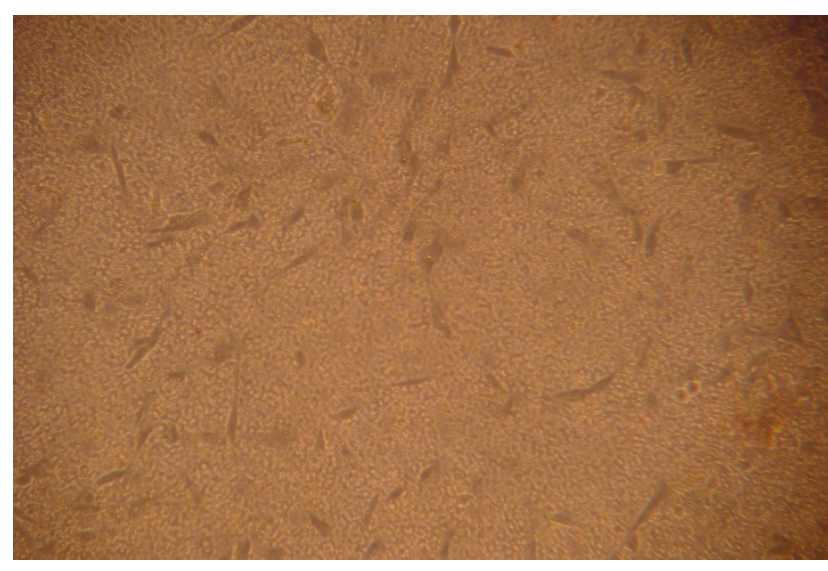

\section{Рис. 3. Колонії стовбурових клітин, отриманих методом цільної крові; \\ 7 день культивування, збільшення $10 \times 20$.}

В процесі досліджень встановлено, що клітини, культивовані за першим методом (розділення клітин в градієнті щільності фіколу), більш активно проліферували, ніж клітини, отримані за другим методом. В культурі клітин, отриманих за другим методом, на 7 день було виявлено більше еритроцитів, ніж стовбурових клітин.

Причому, в культурі клітин, отриманих за другим методом, із застосуванням гепарину, виявлено більше колоній стовбурових клітин, ніж в пробах із цитратом натрію.

Вже на 10-й день на 0-му пасажі при мікроскопії конфлюентність моношару клітин досягала 90\%, а округлі клітини витіснялись фіброподібними клітинами, що свідчить про високу біологічну активність культивованих клітин (рис.4).

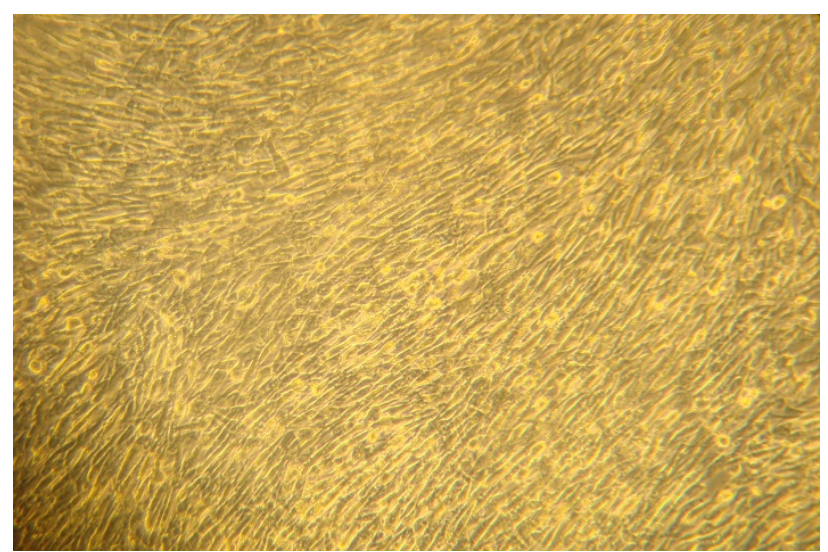

Рис. 4. Колонії стовбурових, клітин отриманих фікольним методом з гепарином;

10 день культивування, збільшення $10 \times 12$.

Встановлено, що в культуральних чашках, з висівом клітин, отриманих другим методом, на 10-й день відмічалось збільшення конфлюентності моно- шару клітин до 80 \%, що майже не поступалось щільності в культурі клітин, отриманих першим методом.

\section{Висновки}

1. Запропонований метод отримання і культивування мультипотентних мезенхімальних стовбурових клітин, виділених з кісткового мозку великої рогатої худоби дає можливість отримувати стовбурові клітини з високою біологічною активністю.

2. Порівняльний аналіз ефективності виділення мезенхімальних стовбурових клітин при використанні гепарину, або цитрату натрію вказує на несуттєві відмінності, що дає можливість використовувати обидва названі препарати в якості стабілізаторів.

3. Культивування мезенхімальних стовбурових клітин методом розділення клітин в градієнті щільності фіколу $(\rho=1,076) \epsilon$ більш ефективним, ніж культивування мезенхімальних стовбурових клітин за другим методом.

Перспективи подальиих досліджень будуть спрямовані на подальше вивчення клітин здатних при індукції формувати клітини кісткового мозку in vitro, які являють собою перспективний матеріал для сільськогосподарської біотехнології.

\section{Бібліографічні посилання}

Fridenshtejn, A.Ja., Chajlahjan, R.K., Lalykina, K.S. (1970). O fibroblastopodobnyh kletkah v kul'turah krovetvornyh tkanej morskih svinok. Citologija. 12, 1147 - 1155 (in Russian).

Minguell, J.J. (2001). Mesenchymal stem cells. Exp. Biol. Med. 226, $507-520$.

Mazurkevych, A.Y., Malyuk, M.O., Kovpak, V.V., Kharkevych, Yu.O., Zhurba, V.I. (2013). Stovburovi klityny u veterynarniy medytsyni. K.: TsP "Komprynt" (in Ukrainian).

Volkova, I.M., Viktorova, E.V., Savchenkova, I.P., Guljukin, M.I. (2012). Harakteristika mezenhial'nyh stvolovyh kletok, vydelenyh iz kostnogo mozga i zhirovoj tkani krupnogo rogatogo skota. Sel'skohozjajstvennaja biologija. 2, 32 - 38 (in Russian).

Smith, R.K., Korda, M., Blunn, G.W., Goodship, A.E. (2003). Isolation and implantation of autologous equin mesenchymal stem cells from bone marrow into the superficial digital flexor tendon as a potential novel treatment. Equine Vet. 35(1), 99 - 102.

Savchenkova, I.P., Guljukin, M.I. (2011). Perspektivy ispol'zovanija stvolovyh kletok $\mathrm{V}$ veterinarii. Veterinarija. 7, 3-5 (in Russian).

Mazurkevych, A.Y., Kovpak, V.V., Danilov, V.B. (2014). Klitynni tekhnolohiyi u veterynarniy medytsyni. K. (in Ukrainian).

Стаття надійшла до редакиії 19.09.2016 